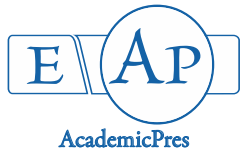

Brahmi M et al. (2020)

Notulae Scientia Biologicae 12(3):578-591

DOI: $10.15835 / \mathrm{nsb} 12310758$

Research Article

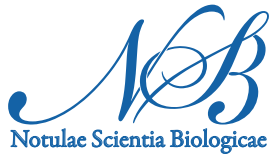

\title{
Beneficial effect of Mentha spicata essential oil on lead and manganese induced nephrotoxicity and oxidative damage in rat kidney
}

\author{
Mostapha BRAHMI*, Djallal E. H. ADLI, Kaddour ZIANI, \\ Hemida HOUARI, Miloud SLIMANI, Khaled KAHLOULA
}

University of Dr Moulay Tahar, Faculty of Sciences, Department of Biology, Laboratory of Biotoxicology, Pharmacognosy and Biological Valorization of Plants (LBPVBP), Saida, Algeria; mostapha.brahmi20@gmail.com ("corresponding author); djillou2006@yahoo.fr; zianivet07@gmail.com; hemidahouari@yahoo.fr; mslimani20@gmail.com; bombixc2@yahoo.fr

\begin{abstract}
Our work focused on the impact of chronic lead acetate and manganese chloride poisoning on renal function in Wistar rats. It also tested the efficacy of the essential oil extracted from (Mentha spicata) spearmint in reversing these effects by treating previously poisoned rats with a daily intraperitoneal injection of $0.1 \mathrm{ml}$ $\mathrm{HEM} / \mathrm{kg}$ over a 21-days period. Analysis of this essential oil through gas chromatography coupled with mass spectrometry revealed that the main components are: carvone (42.2\%), menthone (20.89\%), piperitenone (17.41\%) and isomenthone (7.99\%). Chronic oral co-exposure to lead and manganese during periods of gestation and lactation resulted in a significant reduction $(\mathrm{P}<0.01)$ in both body and kidney weight. Further examination of renal function revealed significant disturbances in the quantity of markers of renal function (creatinine, urea, uric acid) in the blood. Chronic co-exposure led to the observation of disruption to antioxidant enzyme (superoxide dismutase, glutathione peroxidase and catalase) activity in poisoned rats in comparison with the control rats; these results suggest renal failure. Indeed, histological study of the kidneys revealed pronounced damage manifesting as cell degeneration with the renal parenchyma affected by inflammation. In addition, the administration of the essential oil of Mentha spicata led to the observation of an increase in body weight, regulation of the various biochemical markers, and the regeneration of damaged renal tissue, all of which proves the high importance of spearmint in traditional medicine, and its therapeutic properties in combating renal problems.
\end{abstract}

Keywords: GC-MS; kidneys; lead; manganese; Mentha spicata; oxidative stress

\section{Introduction}

The heavy metals are a group of environmental chemicals which are both universal and nonbiodegradable. Although the adverse effects resulting from exposure to them are well-known, their use and environmental concentration are increasing (Zhao et al., 2014). Numerous studies have revealed the toxicity of individual metals for living organisms (Basile et al., 2012). However, these metals do not only exist individually, but also combined in the environment (Smith et al., 2012). 
In fact, lead is a non-essential element for the human body, due to its dispersal in the ambient air, as well as in many foods. Its toxicity is closely tied to its accumulation in certain tissues, and its interference with bioelements, whose role is essential for a number of physiological processes. It has numerous adverse effects, including neurological, behavioral, immunological, renal, hepatic, and in particular hematologic disorders (Annabi et al., 2007).

As for manganese (Mn), an essential metal found in various biological tissues, it is required for the normal functioning of numerous physiological processes, including amino acids, lipids, and protein and carbohydrate metabolism (Erikson et al., 2005). It also plays a vital role in the functioning of the immune system, cellular energy regulation, bone growth, and blood coagulation (Erikson et al., 2003). However, in excessive quantities it may cause damage to the nervous system and enzyme activity (Aschner et al., 2006).

In addition, the clinical importance of plant-based therapeutics (phytotherapy) has received considerable attention recently, as they are a rich source of medicines and produce a wide range of bioactive molecules (Small et al., 2000). The significant nephroprotective activity of numerous medicinal plants and plant extracts has been reported in animal models (Lakshmi et al., 2012). Among these plants Mentha spicata L., commonly called "naana" in Algerian medical systems, has many culinary and medicinal uses in the Maghreb. It is popularly consumed in the form of tea and added to several preparations as a flavour enhancer; dry or fresh spearmint leaf is added especially during tea brewing. Biliary disorders, menstrual pain, stomach aches, constipation, gingivitis and waving are treated with decoction of spearmint leaves (Brahmi et al., 2012).

All these properties, typical of mint species, have been attributed to the combination of essential oil, essentially based on monoterpenoids (Brada et al., 2007), and polyphenolic derivatives (Dorman et al., 2003).

This study examined the impact of chronic co-exposure to lead acetate and manganese chloride at the kidney level in Wistar rats during intrauterine life, lactation and after weaning, and then evaluated the effect of the essential oil of the plant Mentha spicata attenuated this nephrotoxicity in rats intoxicated by these two metals.

\section{Materials and Methods}

Extraction and determination of the chemical composition of the essential oil through GC/MS

Spearmint (Mentha spicata) leaves were harvested in Sidi Maamar, Saida province, located on the high plateaus of western Algeria, before being identified by expert taxonomists (Prof. Hasnaoui and Dr. Sitayeb). The sample was preserved, while the voucher specimen, designated P-200886, was taken to the herbarium at the biology department of the faculty of sciences at the University of Saida, Algeria, for future reference. The analytical study of the essential oil of Mentha spicata was performed by gas chromatography (VARIAN CHROMPACK - CP 3900, injection of $0.1 \mu \mathrm{l}$ of extract) at the quality analysis laboratory in Oran province. Helium (He) was used as the carrier gas at a flow of $1.2 \mathrm{ml} / \mathrm{min}$. The column used was a Chrivasil-Dex CB fused silica CP-type capillary column with a length of $30 \mathrm{~m}$ and an internal diameter of $0.25 \mathrm{~mm}$. Thickness in the stationary phase was $0.25 \mu \mathrm{m}$; the initial injection temperature was set to $70{ }^{\circ} \mathrm{C}$ for 2.5 minutes, then increased by increments of $5^{\circ} \mathrm{C} / \mathrm{min}$ up to $280^{\circ} \mathrm{C}$; a mass spectrometer (Saturn 2200) was used as the sensor for this analysis, with a temperature of $280^{\circ} \mathrm{C}$. The apparatus was operated by a computer guided by software suited to this type of analysis, and an NIST data bank which enabled the identification of the compounds.

\section{Distribution of lots}

The experiments were carried out on Wistar rats, weighing from 200 to $400 \mathrm{~g}$. The rats are grouped in cages at a rate of 2 females and one male. They are placed in a ventilated animal house, at a temperature of 21 ${ }^{\circ} \mathrm{C} \pm 1{ }^{\circ} \mathrm{C}$ with artificial lighting which establishes a day/night cycle (day between 7 and $19 \mathrm{~h}$ ). On the first day of gestation, females are divided into two groups: 
The intoxication of females begins on the first day of cohabitation with male rats which is represented by $\mathrm{D}_{0}$ and continues during the gestation period. Newborns are also exposed to $\mathrm{Pb}-\mathrm{Mn}$ until weaning ( 21 days after birth). Progeny are subject to the same experimental condition.

- Group Pb-Mn: consisting of animals which receive orally lead acetate $\left(\mathrm{Pb}\left(\mathrm{C}_{2} \mathrm{H}_{3} \mathrm{O}_{2}\right)_{2}\right)$ at $0.2 \%$ and manganese chloride tetrahydrate $\left(\mathrm{MnCl}_{2} 4 \mathrm{H}_{2} \mathrm{O}\right)$ at $4.79 \mathrm{mg} / \mathrm{ml}$ in bidistilled water orally from the first day of gestation until weaning ( $\mathrm{n}=07$ male rats) (Kahloula et al., 2009; Molina et al., 2011; Brahmi et al., 2018).

- Group control: consisting of animals which receives the distilled water. Tested offspring are subject to the same conditions as their mother.

- Group T-HEM: 24 hours after weaning, animals receiving distilled water are treated with HEM mint essential oil $(0.1 \mathrm{ml} / \mathrm{kg})$ with one intraperitoneal injection per day for 21 days ( $\mathrm{n}=07$ male rats)

- Group Pb-Mn-HEM: 24 hours after weaning, animals receiving Pb-Mn are treated with HEM mint essential oil $(0.1 \mathrm{ml} / \mathrm{kg})$ with one intraperitoneal injection per day for 21 days ( $\mathrm{n}=07$ male rats) (Halder et al.2011; Brahmi et al., 2019).

- The number of suffering animals were minimized in accordance with the guidelines of the European Council Directive (86/609/EEC).

-

\section{Body and kidney weight}

The body weight of each animal was daily recorded throughout the duration of the experiment. The left kidney weights of different groups of animals were registered.

\section{Biochemical tests}

Lead and manganese analysis in tissues of kidney

Depositing $1 \mathrm{~g}$ fresh weight of each sample with $1 \mathrm{ml}$ of nitric acid $\left(\mathrm{HNO}_{3}\right)$ at $65 \%$ purity, we bring the temperature to $95^{\circ} \mathrm{C}$ for one hour, after cooling; we supplement the content to $4 \mathrm{ml}$ of double distilled water. The lead and manganese concentrations were determined in the organs by atomic absorption spectrophotometry (SHIMA DZU AA6200) and the values were expressed in $\mu \mathrm{g} \mathrm{g}^{-1}$

\section{Determination of kidney parameters}

Serum concentrations of urea, uric acid and creatinine (Murray and Kaplan, 1984) were determined colorimetrically as measures of kidney functions.

\section{Measuring the activity of antioxidant enzymes}

The kidney of the rats was weighed and homogenized in a buffer solution containing $0.32 \mathrm{M}$ sucrose, $0.5 \mathrm{mM}$ EDTA, $10 \mathrm{mM}$ Tris-Hcl ( $\mathrm{pH} 7.4)$ in ice ( $1 \mathrm{mg}$ tissue / $4 \mathrm{ml}$ buffer solution), using a glass tissue homogenizer. The tissue was kept at a temperature of $4{ }^{\circ} \mathrm{C}$ throughout the dissection and homogenization procedures. The homogenate was centrifuged at $1000 \mathrm{x}$ g for $15 \mathrm{~min}$ at $4{ }^{\circ} \mathrm{C}$. The resulting supernatant was also centrifuged at $1000 \mathrm{xg}$ for $15 \mathrm{~min}$ at $4^{\circ} \mathrm{C}$. The pellet consisted of the mitochondrial fraction, and the supernatant was re-centrifuged at $10.000 \mathrm{x}$ g for 30 minutes. The two resultant pellets were made soluble in a buffer solution containing $0.32 \mathrm{M}$ sucrose, $0.5 \mathrm{mM}$ EDTA, $10 \mathrm{mM}$ Tris- $\mathrm{Hcl}$ and $0.02 \%$ digitonin ( $\mathrm{pH} 7.4$ ). The digitonin was added to liberate any mitochondria entrapped in the synaptosomes, and centrifuged a second time at $10.000 \mathrm{xg}$ for $15 \mathrm{~min}$ at $4^{\circ} \mathrm{C}$. The resultant pellet consisted of the total mitochondrial fraction, which was made soluble in a solution containing sucrose (0.32 M at pH 7.4) (Michaux, 1971). The superoxide dismutase (SOD) (EC 1.15.1.1) was analyzed in the supernatant using the technique of Kakkar (1984); this method is based on inhibiting the formation of nicotinamide adenine dinucleotide, phenazine methosulfate and formazan blue tetrazolium. The activities and antioxidant levels in the kidneys, as well as those of catalase (CAT) and glutathione peroxidase (Gpx) were analyzed using the methods of Sinha, (1972) and Rotruck, (1973), respectively. 


\section{Histological study}

Samples of Kidney spleen were collected and fixed in $10 \%$ buffered neutral formalin solution, dehydrated in gradual ethanol (70-100\%), cleared in xylene, and embedded in paraffin. Paraffin sections $(5 \mu \mathrm{m}$ thick) were prepared, routinely stained with hematoxylin and eosin (H\&E) dyes (Suvarna et al., 2013), and then examined microscopically

\section{Statistical analysis}

The results are expressed as the mean $(\mathrm{M})$ of the individual values, subject to standard error of the mean (SEM). Multiple means are compared through analysis of variance (ANOVA) with the intoxication factor $(\mathrm{Pb}$ $\mathrm{Mn}, \mathrm{T}$ ). ANOVAs with repeated measures were used to analyze the time factor. A probability of $\mathrm{p}<0.05$ is considered significant. Statistical analyses were performed using the Sigma Stat software (SPSS Inc., Chicago, IL, USA).

\section{Results}

\section{The yield of essential oil}

The hydro-distillation of the plant matter Mentha spicata allowed to obtain a yield of $0.83 \%$. The analysis of the essential oil of Mentha spicata by gas chromatography identified 12 major compounds listed in Table 1 by order of elution. Twelve components representing the sum of the percentages of the components obtained were identified (98.51\%), of which $96.71 \%$ are monoterpene ketones, $1.75 \%$ are monoterpene hydrocarbons, $0.05 \%$ are oxides. The major components of this oil are: carvone (42.2\%), menthone (20.89\%), piperitenone (17.41\%) and isomenthone (7.99\%) (Table 1).

Table 1. Concentration in $\%$ and retention time of the different compounds obtained by gas chromatographic analysis of the essential oil of M. spicata

\begin{tabular}{|c|c|c|}
\hline Compounds & Retention time (min) & Concentration (\%) \\
\hline$\alpha$-pinene & 11.200 & 0.40 \\
\hline Sabinene & 12.080 & 0.56 \\
\hline$\beta$-pinene & 12.440 & 0.70 \\
\hline Octane-3-one & 12.820 & 1.15 \\
\hline Paracymen & 13.600 & 0.09 \\
\hline 1.8 cineole & 14.110 & 0.05 \\
\hline Menthone & 18.213 & 20.89 \\
\hline Isomenthone & 18.710 & 7.99 \\
\hline Pulegone & 21.460 & 0.05 \\
\hline Carvone & 21.480 & 42.2 \\
\hline Piperiton & 22.010 & 7.02 \\
\hline Piperitenone & 23.150 & 17.41 \\
\hline \multicolumn{2}{|l}{} \\
\hline
\end{tabular}

\section{Effects on the body and the kidney weight}

The results show that the animals exposed to $\mathrm{Pb}-\mathrm{Mn}$ presented a significant reduction $(\mathrm{p}<0.01)$ in body weight compared to that of the control animals during the experiment. Additionally, the animals exposed to $\mathrm{Pb}-\mathrm{Mn}$ and treated with MEO showed a significant increase $(\mathrm{p}<0.001)$ in body weight in comparison with the untreated rats (Figure 1). 


\section{Body weights (g)}

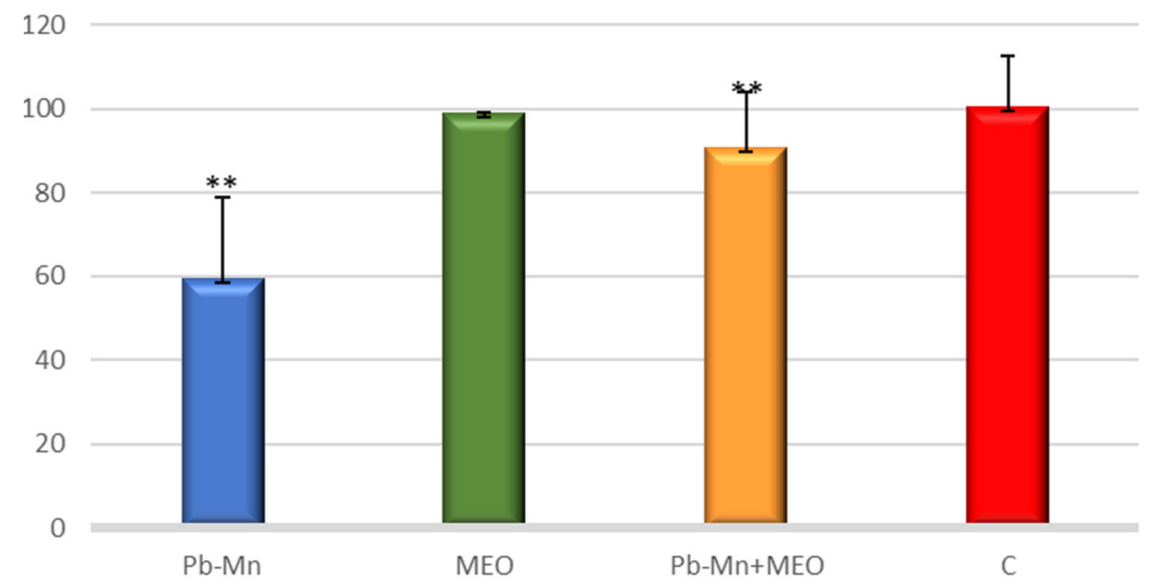

Figure 1. Effect of $M$. spicata essential oil on the body weight in rats intoxicated ( $\mathrm{Pb}-\mathrm{Mn})$

Data are mean \pm S.E.M. ${ }^{* *} \mathrm{P}<0.01,(\mathrm{~Pb}-\mathrm{Mn}$ vs. $\mathrm{C})$.

The results found in the poisoned animals also reveal a significant decrease $(\mathrm{p}<0.01)$ in kidney weight compared to the control group (Figure 2). On the other hand, the animals treated with MEO showed a significant increase $(\mathrm{p}<0.01)$ in the weight of the studied organ in comparison with the untreated rats).

\section{Kidney weights (g)}

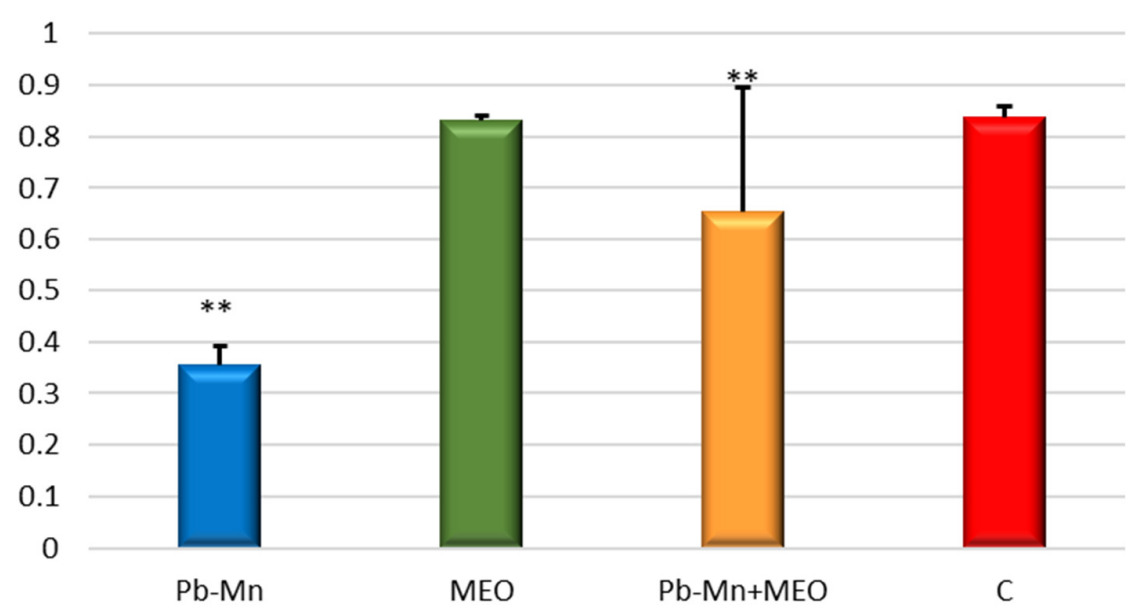

Figure 2. Effect of $M$. spicata essential oil on the kidney weight in rats intoxicated (Pb-Mn)

Data are mean \pm S.E.M. ${ }^{* *} \mathrm{P}<0.01$, (Pb-Mn vs. C).

The results show that the concentration of lead and manganese in the kidney was significantly higher ( $\mathrm{p}$ $<0.01)$ in the poisoned rats compared to the control rats. The administration of the essential oil led to the recording of a significant reduction $(\mathrm{p}<0.01)$ in the levels of lead and manganese in the kidneys (Table 2$)$.

Biochemical analysis of the renal biomarkers at the end of the experiment showed a significant increase in creatinine, urea and uric acid in the rats exposed to $\mathrm{Pb}-\mathrm{Mn}$ compared to the control rats. This shows that these two metals lead to renal dysfunction (Table 2). After 3 weeks of MEO treatment, we observed a clear correction of the concentration of creatinine, urea and uric acid in the plasma of the previously poisoned rats. 
Table 2. Effect of the essential oil of the M. spicata plant on the various biochemical parameters in rats intoxicated by $\mathrm{Pb}-\mathrm{Mn}$ compared to control rats

\begin{tabular}{|l|c|c|c|c|}
\hline & $\mathrm{Pb}-\mathrm{Mn}$ & $\mathrm{MEO}$ & $\mathrm{Pb}-\mathrm{Mn}+\mathrm{MEO}$ & $\mathrm{C}$ \\
\hline $\mathrm{Pb}(\mu \mathrm{g} / \mathrm{g})$ & $40.41 \pm 0.15^{*}$ & $0.55 \pm 0.17$ & $21.13 \pm 0.10^{*}$ & $0.51 \pm 0.08$ \\
\hline $\mathrm{Mn}(\mu \mathrm{g} / \mathrm{g})$ & $138 \pm 0.02^{* *}$ & $99 \pm 0.04$ & $111.2 \pm 0.1^{* *}$ & $93 \pm 0.10$ \\
\hline Urea $(\mathrm{mg} / \mathrm{dl})$ & $4.40 \pm 0.20^{* * *}$ & $2.89 \pm 0.20$ & $3.99 \pm 0.29^{* * *}$ & $2.72 \pm 0.18$ \\
\hline Uric acid $(\mathrm{mg} / \mathrm{dl})$ & $6.11 \pm 0.45^{* *}$ & $3.017 \pm 0.26$ & $4.14 \pm 0.25^{* *}$ & $3.50 \pm 0.56$ \\
\hline Creatinine $(\mathrm{mg} / \mathrm{dl})$ & $10.84 \pm 0.25^{* *}$ & $7.55 \pm 0.22$ & $8.33 \pm 0.05^{* *}$ & $7.40 \pm 0.38$ \\
\hline
\end{tabular}

Data are mean \pm SEM $\left(* * *: p<0.001,{ }^{* *}: \mathrm{p}<0.01,{ }^{*}: \mathrm{p}<0.05\right)$

\section{Renal antioxidant enzyme activity}

The renal antioxidant results show a significant decrease in SOD, CAT and GPx in the kidneys of the rats exposed to $\mathrm{Pb}-\mathrm{Mn}$ during the developmental period in comparison with the control rats. Under MEO treatment, on the other hand, a significant increase was observed $(\mathrm{p} \leq 0.05)$ in the group treated following poisoning (Table 3).

Table 3. Effect of M. spicata essential oil in the activity of anti-oxidant enzymes in kidney of rats intoxicated

\begin{tabular}{|c|c|c|c|c}
\hline Groupes & Pb-Mn & MEO & Pb-Mn+MEO & C \\
\hline SOD $(\mathrm{U} / \mathrm{g})$ & $0.51 \pm 0.059^{*}$ & $0.95 \pm 0.09$ & $0.79 \pm 0.019^{*}$ & $1.09 \pm 0.02$ \\
\hline $\mathrm{CAT}(\mathrm{U} / \mathrm{g})$ & $0.36 \pm 0.34^{*}$ & $0.53 \pm 0.07$ & $0.50 \pm 0.02^{*}$ & $0.65 \pm 0.05$ \\
\hline $\mathrm{GPx}(\mathrm{U} / \mathrm{g})$ & $0.73 \pm 0.03^{* *}$ & $0.22 \pm 0.005$ & $0.83 \pm 0.05^{* *}$ & $1.23 \pm 0.33$ \\
\hline
\end{tabular}

\section{Effect of Pb-Mn on the structural architecture of the kidney}

The histological study of renal tissue in rats suffering from $\mathrm{Pb}-\mathrm{Mn}$ poisoning (Figure 3B) shows considerable tubular degeneration with renal failure. The organization of the tissue presented a renal parenchyma affected by inflammation caused by active congestion and an edema. There was also evidence of partial necrosis of the convoluted tubules (presence of homogeneous cytoplasm cells lacking nuclei).

In the same context, the animals exposed to $\mathrm{Pb}-\mathrm{Mn}$ and treated with $\mathrm{MEO}$ presented regeneration of the tissue with a renal parenchyma showing signs of a minor inflammatory reaction caused by minor inflammatory lymphocytic infiltrate (Figure 3C).

Furthermore, observation through an optical microscope of the renal tissue of the control rats and the rats treated with $\mathrm{MEO}$ showed a normal structure in the renal tubules and glomeruli (Figure $3 \mathrm{~A}-\mathrm{D}$ ). 

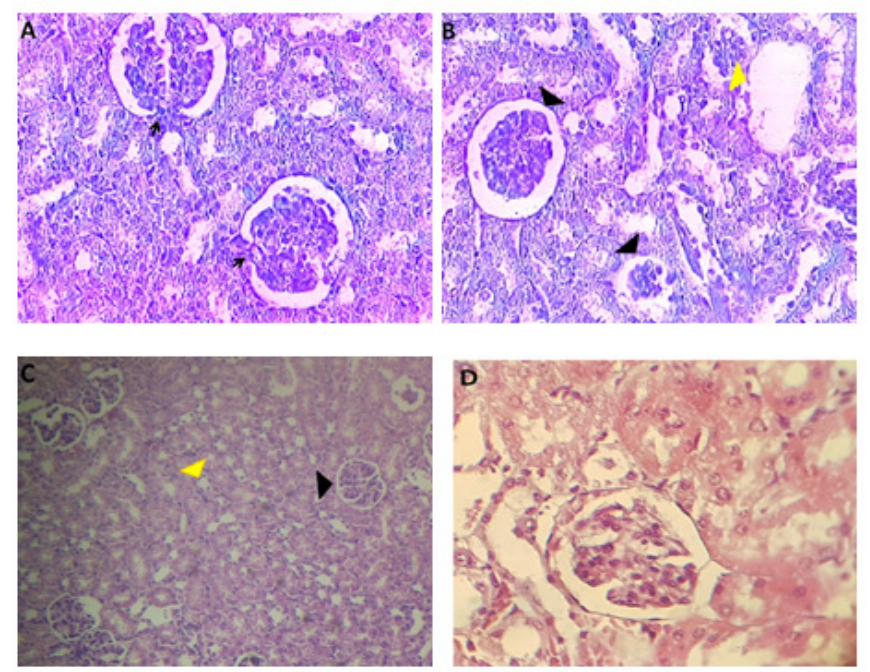

Figure 3. Section of renal rat tissue with hematoxylin and eosin (G:x20); (A) normal architecture and normal Bowman capsule $\Leftrightarrow$ in the control group $(T)$ (Animals received distilled water) and the group MEO (D),(Animals received essential oil); (B) group (Mn-Pb), (Intoxicated animals) Showing degeneration of Bowman capsules $(\boldsymbol{\Lambda})$, with large interstitial spaces and complete absence of bypassed tubes $(\triangle) ;(\mathrm{C})$ the group exposed to $(\mathrm{Mn}-\mathrm{Pb})$ and treated with essential oil, Showing the regeneration of the majority of Bowman's capsules $($ ) and interstitial cells, with convoluted tubes ( )

\section{Discussion}

The essential oil of Mentha spicata (MEO) has been obtained through hydro-distillation with a yield of $0.83 \%$, a figure that contradicts the work of (Priscilla et al., 2010$)$, which reported a value of $(0.23 \pm 0.4 \%)$ and that of (Lucchesi et al., 2004) $(0.60 \pm 0.06 \%)$. This difference in yield can be attributed to multiple factors, the most significant being the origin, species, harvesting time, length of drying period and technique used to extract the essential oils (Karousou et al., 2005). Furthermore, Marotti et al. (1994) have shown that weak yields can be associated with a series of factors such as the genotype, the growth stages of the plant, and the environmental conditions of semi-arid regions.

Nevertheless, the GC-MS of this herb first and foremost includes an essential oil with various chemical components of diverse natures, such as Carvone (42.2\%), Menthone (20.89\%), Piperitenone (17.41\%) and Isomenthone (7.99\%). These results corroborate those of (de Sousa Barros et al., 2015), which show that this oil consists principally of carvone.

The results recorded clearly show that the weight of the animals exposed to $\mathrm{Pb}-\mathrm{Mn}$ during the prenatal period was significantly lower than that of the control animals, which manifested as a decrease in body weight gain. This can be explained by the anorectic effect of $\mathrm{Pb}-\mathrm{Mn}$ and their impact on the nervous centers responsible for the regulation of satiety and hunger. Our results are in keeping with the work undertaken by various authors (Torres and Nowson, 2007; Ibrahim et al., 2012). They observed a reduction in the food consumption of poisoned rats depending on the dose administered and the duration of exposure. Furthermore, we have observed that the administration of lead acetate leads to a reduction in kidney weight, which suggests disruption to their function and which may be due to the effect of $\mathrm{Pb}$ and $\mathrm{Mn}$ on neuronal proliferation and differentiation in the course of the prenatal period (Smith et al., 2008; Ming et al., 2015).

Consequently, the administration of the essential oil of Mentha spicata to rats previously exposed to $\mathrm{Pb}$ $\mathrm{Mn}$ led to the observation of a clear increase in body weight gain in comparison with the animals left untreated following exposure to $\mathrm{Pb}-\mathrm{Mn}$. This recorded increase in weight could be due to the presence of terpenoid compounds, which act to stimulate the transport of glucose in cells (Vinay Dwivedi et al., 2011). Our 
observations are also in keeping with those of (Toghyani et al., 2010), who reported that the addition of peppermint powder to the diet of table chickens at a level of $4 \mathrm{~g} / \mathrm{kg}$ led to an increase in body weight gain. The same has also been shown by Zargari. (2002); that the addition of medicinal plants stimulates appetite and the secretion of gastrointestinal fluids, and improves digestion and absorption, thus resulting in body weight gain.

The results recorded for poisoned rats showed an accumulation of $\mathrm{Pb}$ and $\mathrm{Mn}$ in the kidneys. Han et al. (1996) has suggested that this factor is closely linked to macromolecules in the intracellular compartment, as lead-binding proteins have been isolated from the kidney, liver, blood and brain, explaining the high concentration of $\mathrm{Pb}$ in the kidney tissue found in this study.

In our study, we have observed a significant increase in the levels of urea and creatinine in the blood of animals with $\mathrm{Pb}-\mathrm{Mn}$ poisoning. These results are in keeping with the work of (Thylambal and Saroja, 2004; Abdel Moneim et al., 2011), who have shown that the renal cells are no longer capable of controlling the urinary excretion process, as the kidneys are among the organs most sensitive to lead. In addition, according to the study of Saka et al. (2011), the increase of serum urea and creatinine in rats exposed to $\mathrm{Pb}$ is due to the degradation of hepatic protein

Compounds, whereby the proteins may be broken down into amino acids, and then again into urea and creatinine. In this way, when exposed to serum aminotransferase, these amino acids may be converted into carboxylic compounds such as pyruvic acid. According to (Michaux et al., 1971), this is the result of a reduction in the rate of glomerular filtration.

Even so, Sánchez-González et al. (2015) have found that Mn also plays a role in chronic renal failure, which in turn causes an increase in urea and creatinine levels, which may be due to the adverse effect of manganese on calcium ions $\left(\mathrm{Ca}^{+2}\right)$ during the glomerular filtration processes. The results obtained are also corroborated by those of Madlala et al. (2012); Sánchez-González et al. (2015) who found that Mn plays a role in chronic renal failure, which leads to an increase in urea and creatinine levels. This hypercreatininemia may be a result of the accumulation of manganese in the various cellular compartments of the kidney.

Endogenous antioxidant enzymes are responsible for the neutralization of free radicals, as well as preventing their damaging effect on tissue. Oxidative stress is a result of an imbalance between the production of reactive oxygen species (ROS) and antioxidant defenses, which in turn leads to a series of events deregulating cell functions. Antioxidant enzymes such as SOD, CAT and GPx form a united defensive front against ROS (Bandyopadhyay et al., 1999). Our results show that lead acetate and manganese caused a significant reduction in the concentration of SOD, CAT and GPx in the kidneys of rats suffering from $\mathrm{Pb}$ and $\mathrm{Mn}$ poisoning in comparison with the control rats.

It has been demonstrated that the accumulation of lead in the various cellular compartments of the liver leads to oxidative damage through an increase in lipid peroxidation and protein oxidation, a deleterious process caused only by free radicals (Villeda-Hernandez et al., 2001; Kong et al., 2004).

The activity of superoxide dismutase (SOD) is significantly reduced in the renal tissue of the poisoned rats compared to the controls group, which could be due to the mass production of superoxide anions and a deficiency of copper as an enzymatic cofactor (Matés et al., 2000). SOD plays a very important role in the antioxidant system through the disproportionation of the superoxide anion to form $\mathrm{H}_{2} \mathrm{O}_{2}$ and $\mathrm{O}_{2}$ (Mylorie et al., 2001).

The reduction in catalase in the kidney tissue of poisoned rats compared to the control rats could be due to the effect of lead on the active components of the cellular defense system through a change in the activity of said enzyme (Alghazall et al., 2008).

Numerous works suggest that exposure to Mn leads to various cellular changes, due to an increase in oxidative stress and the failure of the metabolic energy and antioxidant systems (Dobson et al., 2004).

Recent studies have revealed the link between oxidative stress and mitochondrial dysfunction resulting from exposure to this metal (Mn) (Milatovic et al., 2007). Furthermore, one particular hypothesis has been posited suggesting that $\mathrm{Mn}$ poisoning is associated with mitochondrial dysfunction, which builds up 
preferentially in the mitochondrial matrix (Liccione et Maines. 1988), reflecting its high affinity with calcium (Gavin et al., 1999).

Oxidative stress caused by high concentrations of $\mathrm{Mn}$ leads to the induction of pores to open and the mitochondrial permeability of said pores, dependent on $\mathrm{Ca}^{+2}$, which leads to an increase in the solubility of protons, ions and solutes, the potential loss of the internal mitochondrial membrane, a decline in the effects of oxidative phosphorylation and ATP synthesis, and mitochondrial swelling (Yin et al., 2008).

Multiple observations have demonstrated that intracellular GSH levels are affected by Mn poisoning, and that deficiency in mitochondrial function is a key mechanism in Mn poisoning (Dukhande et al., 2006). For example, $\mathrm{Mn}^{+2}$ can replace $\mathrm{Fe}^{+2}$ in the cytochromes of the cellular respiration chain (with a similar structure to hemoglobin) (Missy et al., 2000), leading to the incomplete reduction of $\mathrm{O}_{2}$ and the formation of free radicals and oxygen compounds such as $\mathrm{O}_{2}$ and $\mathrm{H}_{2} \mathrm{O}_{2}$.

It has been demonstrated that Mn directly inhibits enzymes of the mitochondrial ETC (Electron Transport Chain) (Singh et al., 1979). It could be predicted that this inhibition may also improve the production rate of radicals. An increase in the production of radicals would be further exacerbated by the decrease in GPx and the activities of SOD (Liccione et Maines. 1988).

\section{Effect of Pb-Mn on the structural architecture of the kidney}

In this study, the results of the microscopic examination of histological sections taken from the kidneys of rats suffering from $\mathrm{Pb}-\mathrm{Mn}$ poisoning revealed that the renal parenchyma was affected by inflammation caused by active congestion, an edema, and the partial necrosis of the convoluted tubules. The control rats, on the other hand, presented a normal renal parenchyma, including the renal glomeruli and convoluted tubes, all within interstitial tissue showing no irregularities. These results are in keeping the work undertaken by (Abdel Moneim et al. 2011; Zhang et al. 2013) who showed that $\mathrm{Pb}$ causes histological changes in the kidneys, which develop and are notably characterized by a decrease in glomeruli in the kidney, an inflammatory reaction, cytoplasmic vacuolization, and the dilatation of certain renal tubules. These tubular deformations caused by poisoning could be the result of a hydraulic change in the renal tissue, and suggest that lead poisoning leads to the partial failure of ion pumps in the tubular cells, which in turn causes tubular swelling, leading to necrosis and tubular vacuolization (Karmakar et al., 1986; Wei et al., 2001)

Exposure to manganese chloride causes changes to the renal architecture (inflammation, tubular necrosis). This damage invokes the hypothesis of a state of oxidative stress caused by manganese within the cells (Guilherme et al., 2015). Knowing that manganese can replace different oligo-elements of the same valency within metalloproteins (enzymes), which require the presence of said oligo-elements in their activities and subsequently cause disruption in the various metabolisms.

However, mint is the most popular medicinal plant in the world, and its essential oil is a key part of aromatherapy (Schneider et al., 2000). Spearmint, or Mentha spicata to use its scientific term, is very widely distributed in Algeria, especially in the province of Saïda.

For this reason, the aim of our work is to assess the therapeutic effect of the essential oil of the Mentha spicata plant in cases of lead and manganese poisoning in Wistar rats over the course of the period of development (gestation and lactation).

The administration of MEO to the poisoned rats has shown that treatment with the oil reduced considerably the concentration of lead and manganese in the kidneys. This effect may be due to the presence of chelate compounds, as well as the redox properties of the polyphenols, which allow them to act as antioxidants and reduce the accumulation of the aforementioned elements (Kaisoon et al., 2011).

Furthermore, following the treatment of rats suffering from $\mathrm{Pb}-\mathrm{Mn}$ poisoning with $\mathrm{MEO}$, we noticed a reduction in the levels of urea and creatinine; our results are in keeping with the work of Bellassoued et al. (2018) which concluded that the essential oil of the spearmint plant provides a protective effect against hepatonephrotoxicity. 
In the same context, the histological results for the kidneys of rats suffering from $\mathrm{Pb}-\mathrm{Mn}$ poisoning and treated with $\mathrm{MEO}$ have allowed us to observe a clear improvement in comparison with the untreated rats. The efficacy of MEO in the kidney was perhaps due to the presence of chelate compounds (Ullah et al., 2014). These biologically active compounds can chelate the $\mathrm{Pb}-\mathrm{Mn}$ and increase its excretion from the organism, thus reducing the accumulation of $\mathrm{Pb}$ and $\mathrm{Mn}$ in the renal tissue.

Ullah et al. (2014) has also shown that mint extract (Mentha piperita) reduces tubular necroses in the kidneys induced by gentamicin, and provides protection against renal failure by acting as an antioxidant.

Additionally, the intraperitoneal administration of $\mathrm{MEO}$ at a dose of $0.1 \mathrm{ml} / \mathrm{kg}$ has allowed us to observe a significant increase in SOD and CAT content, and in the activity of GPx in rats exposed to Pb-Mn. Our results are in keeping with Singh et al. (2014); Azab et al. (2017); Bellassoued et al. (2018) which indicate that the force-feeding of hydroalcoholic extract of mint (M. arvensis, $M$. piperita) led to a significant increase in SOD content and GPx activity in rats previously poisoned with $\mathrm{CCl}_{4}$.

Pharmacological studies have shown that the essential oils derived from various plant materials possess anti-inflammatory properties (Kim et al., 2008; Martins et al., 2008). Knowing that terpenes have excellent anti-inflammatory properties (Cowan et al., 1999), the anti-inflammatory properties of the essential oil derived from the leaves of $M$. piperita can in part be explained by the presence of said terpenes. Furthermore, menthol and isomenthone, found in relatively high concentrations in the essential oil of $M$. piperita, have been reported to provide anti-inflammatory activities (Cowan et al., 1999).

Bellassoued et al. (2018) have shown that pretreatment with the essential oil of M. piperita at $40 \mathrm{mg} \mathrm{kg}$ ${ }^{1}$ can also lead to a clear improvement in histopathological kidney damage induced by the administration of $\mathrm{CCl}_{4}$. Other works have revealed that $M$. arvensis provides a nephroprotective effect against the nephrotoxicity of cisplatin in Sprague-Dawley rats, which could be attributable to the presence of flavonoids and related compounds (Singh et al., 2014).

\section{Conclusions}

Exposing Wistar rats to $\mathrm{Pb}-\mathrm{Mn}$ during gestation and lactation revealed nephrotoxic effects which resulted in a significant change to the antiradical system, represented by various enzymes. Treatment with MEO for previously poisoned rats showed significant improvement in the histopathological image of the kidney, as well as general renal function.

\section{Authors' Contributions}

$\mathrm{BM}$ and $\mathrm{ADEH}$ designed and performed the experiments and also wrote the manuscript. ZK performed the biochemical and statistical analysis. HH carried out the histological study. SM and KK reviewed the manuscript. All authors read and approved the final version.

Ethical approval (for researches involving animals or humans)

The number of suffering animals were minimized in accordance with the guidelines of the European Council Directive (86/609/EEC). 


\section{Acknowledgements}

I want to thank all the members of the Laboratory of Biotoxicology, Pharmacognosy and Biological Valorization of Plants (LBPVBP) at the University Dr. Moulay Tahar - Saida - Algeria.

\section{Conflict of Interests}

The authors declare that there are no conflicts of interest related to this article.

\section{References}

Alghazal MA, Sutiakova I, Kovalkovicova N, Legath M, Pistt J, Benova R, ... Vaczi P (2008). The induction of micronuclei in rat bone marrow after chronic exposure to lead acetate trihychate. Journal of Toxicology and Industrial Health 24(9):587-593. https://doi.org/10.1177/0748233708100089

Almeida PP, Mezzomo N, Ferreira SR (2012). Extraction of Mentha spicata L. volatile compounds: evaluation of process parameters and extract composition. Food and Bioprocess Technology 5(2):548-559. https://doi.org/10.1007/s11947-010-0356-y

Aschner M, Lukey B, Tremblay A (2006). The Manganèse Health Research Program (MHRP): statut report and future research needs and directions. Neurotoxicology 221:131-147. https://doi.org/10.1016/j.neuro.2005.10.005

Azab AE, Albasha MO, Elsayed ASI (2017). Prevention of nephropathy by some natural sources of antioxidants. Yangtze Medicine 1:235-266. https://doi.org/10.4236/ym.2017.14023

Bandyopadhyay U, Das D, Banerjee RK (1999). Reactive oxygen species: oxidative damage and pathogenesis. Current Science 658-666. https://doi.org/10.2307/24102839

Basile A, Sorbo S, Conte B, Cobianchi RC, Trinchella F, Capasso C, Carginale V (2012). Toxicity, accumulation, and removal of heavy metals by three aquatic macrophytes. International Journal of Phytoremediation 14:374-387. https://doi.org/10.1080/15226514.2011.620653

Bellassoued K, Hsouna BA, Athmouni K, van Pelt J, Ayadi FM, Rebai T, Elfeki A (2018). Protective effects of Mentha piperita L. leaf essential oil against $\mathrm{CCl}_{4}$ induced hepatic oxidative damage and renal failure in rats. Lipids in Health and Disease 17(1):9. https://doi.org/10.1186/s12944-017-0645-9

Berrahal AA, Nehdi A, Hajjaji N, Gharbi N, El-Fazâa S (2007). Antioxidant enzymes activities and bilirubin level in adult rat treated with lead. Comptes Rendus Biologies 330(8):581-588. https://doi.org/10.1016/j.crvi.2007.05.007

Brada M, Bezzina M, Marlier M, Carlier A, Lognay G (2007). Variability in the chemical composition of essential oils of Mentha rotundifolia from Northern Algeria. Biotechnologie Agronomie Societe et Environnement 11(1):3-7.

Brahmi M, Adli DEH, Slimani M, Arabi W, Taibi N, Kahloula K (2019). Evaluation of the therapeutic effects of Mentha spicata essential oil at the liver level in developing Wistar rats co-exposed to lead and manganese. Carpathian Journal of Food Science \& Technology 11(2). https://doi.org/10.34302/crpjfst/2019.11.2.12

Brahmi M, Adli DEH, Slimani M, Arabi W, Taibi N, \& Kahloula K (2018). Evaluation of anti-oxidative effects of Mentha spicata essential oils in rats at the period of gestation and lactation co-exposed to lead and manganese. South Asian Journal of Experimental Biology 8(5):167-171.

Bresciani G, da Cruz IBM, González-Gallego J (2015). Manganese superoxide dismutase and oxidative stress modulation. In: Advances in Clinical Chemistry 68:87-130. https://doi.org/10.1016/bs.acc.2014.11.001

Chibane M (2012). Optimization of solvent extraction of antioxidants (phenolic compounds) from Algerian mint (Mentha spicata L.). Pharmacognosy Communications 2(4):72-86. https://doi.org/10.5530/pc.2012.4.1

Cowan MM (1999). Plant products as antimicrobial agents. Clinical Microbiology Reviews 12:564-582. https://doi.org/10.1128/CMR.12.4.564

De Sousa Barros A, De Morais SM, Ferreira PAT, Vieira Í (2015). Chemical composition and functional properties of essential oils from Mentha species. Industrial Crops and Products 76:557-564.

Dobson AW, Erikson KM, Aschner M (2004). Manganese neurotoxicity. Annals of New York Academy of Sciences 1012:115-128. https://doi.org/10.1196/annals.1306.009 
Dorman HJD, Kosar M, Kahlos K, Holm Y, Hiltunen R (2003). Antioxidant properties and composition of aqueous extracts from Mentha species, hybrids, varieties, and cultivars. Journal of Agricultural and Food Chemistry 51:4563-4569. https://doi.org/10.1021/jf034108k

Dukhande VV, Malthankar-Phatak GH, Hugus JJ, Daniels CK, Lai JC (2006). Manganese- induced neurotoxicity is differentially enhanced by glutathione depletionin astrocytoma and neuroblastoma cells. Neurochemical Research 31:1349-1357. https://doi.org/10.1007/s11064-006-9179-7

Dwivedi V, Shrivastava R, Hussain S, Ganguly C, Bharadwaj M (2011). Comparative anticancer potential of clove (Syzygium aromaticum)-an Indian spice-against cancer cell lines of various anatomical origin. Asian Pacific Journal of Cancer Prevention 12:1989-1993.

Erikson KM, Aschner M (2003). Manganese neurotoxicity and glutamate-GABA interaction. Neurochemistry International 43:475-480. https://doi.org/10.1016/s0197-0186(03)00037-8

Erikson KM, Syversen T, Aschner JL, Aschner M (2005). Interactions between excessive manganese exposures and dietary iron-deficiency in neurodegeneration. Environmental Toxicology and Pharmacology 19:415-421. https://doi.org/10.1016/j.etap.2004.12.053

Gavin CE, Gunter KK, Gunter TE (1992). $\mathrm{Mn}^{2+}$ sequestration by mitochondria and inhibition of oxidative phosphorylation. Toxicology and Applied Pharmacology 115:1-5. https://doi.org/10.1016/0041$008 X(92) 90360-5$

Halder S, Mehta AK, Kar R, Mustafa M, Mediratta PK, Sharma KK (2011). Clove oil reverses learning and memory deficits in scopolamine-treated mice. Planta Medica 77:830-834. https://doi.org/10.1055/s-0030-1250605

Han SX, Qiao S, Simpson P, Ameri FW, Kemp JD (1996). Weight loss alters organ concentrations and contents of lead and some essential divalent metals in rats previously exposed to lead. The Journal of Nutrition 126:317-323.

Ibrahim NM, Eweis EA, El-Beltagi HS, Abdel Mobdy YE (2012). Effect of lead acetate toxicity on experimental male albino rats. Asian Pacific Journal of Tropical Biomedicine 2(1):41-46. https://doi.org/10.1016/S22211691(11)60187-1

Kahloula K, Slimani M, Dubois M, Bonnet JJ (2009). D-cycloserine enhances spatial learning performances of rats chronically exposed to lead during the developmental period. Synthèse: Revue des Sciences et de la Technologie 20(2009):48-57.

Kaisoon O, Siriamornpun S, Weerapreeyakul N, Meeso N (2011). Phenolic compounds and antioxidant activities of edible flowers from Thailand. Journal of Functional Foods 3(2):88-99. https://doi.org/10.5281/zenodo.995637

Kakkar P, Das B, Viswanathan PN (1984). A modified spectrophotometric assay of superoxide dismutase. Indian Journal of Biochemistry and Biophysics 21:130-132.

Karmakar N, Saxena R, Anand S (1986). Histopathological changes induced in rat tissues by oral intake of lead acetate. Environmental Research 41:23-28. https://doi.org/10.1016/S0013-9351(86)80164-5

Karousou R, Koureas DN, Kokkini S (2005). Essential oil composition is related to the natural habitats: Corido Thymus capitatus and Satureja thymbra in Natura 2000. Phytochemistry 66:2668-2673. https://doi.org/10.1016/j.phytochem.2005.09.020

Kim JY, Oh TH, Kim BJ, Kim SS, Lee NH, Hyun CG (2008). Chemical composition and anti-inflammatory effects of essential oil from Farfugium japonicum flower. Journal of Oleo Science 5:623-628. https://doi.org/10.5650/jos.57.623

Kong LD, Christopher H, Cheng K, Tan RX (2004). Inhibition of MAO A and B by some plant derived alkaloids, phenols and anthraquinones. Journal of Ethnopharmacology 91:351-355. https://doi.org/10.1016/j.jep.2004.01.013

Lakshmi MS, Reddy UK and Rani SRKS (2012). A review on medicinal plants for nephroprotective activity. Asian Journal of Pharmaceutical and Clinical Research 5:8-14. https://doi.org/10.30574/gscbps.2019.8.1.0108

Liccione JJ, Maines MD (1988). Selective vulnerability of glutathione metabolism and cellular defense mechanisms in rat striatum to manganese. Journal of Pharmacology and Experimental Therapeutics 247:156-161.

Lucchesi ME, Chemat F, Smadja J (2004). Solvent free microwave extraction of essential oil from aromatic herbs: Comparison with conventional hydro-distillation. Journal of Chromatography A 1043:323-327. https://doi.org/10.1016/j.chroma.2004.05.083

Madlala HP, Masola B, Singh M, Musabayane CT (2012). The effects of Syzygium aromaticum-derived oleanolic acid on kidney function of male Sprague-Dawley rats and on kidney and liver cell lines. Renal Failure 34(6):767-76. https://doi.org/10.3109/0886022X.2012.678172 
Marotti M, Piccaglia R, Giovanelli E, Deans SG, Eaglesham E (1994). Effects of planting time and mineral fertilization on peppermint (Mentha piperita L.) essential oil composition and its biological activity. Flavour and Fragrance Journal 9(3):125-129.

Martins FT, Doriguetto AC, De Souza TC, De Souza KR, Moreira ME, Barbosa LC (2008). Composition, and antiinflammatory and antioxidant activities of the volatile oil from the fruit peel of Garcinia brasiliensis. Chemistry and Biodiversity 5:251-258.

Matés JM (2000). Effects of antioxidant enzymes in the molecular control of reactive oxygen species toxicology. Toxicology 153:83-104. https://doi.org/10.1016/s0300-483x(00)00306-1

May B, Schneider B, Köhler S (2000). Efficacy and tolerability of a fixed combination of peppermint oil and caraway oil in patients suffering from functional dyspepsia. Alimentary Pharmacology and Therapeutics 14(12):1671-1677. https://doi.org/10.1046/j.1365-2036.2000.00873.x

Michaux P, Boiteau HL, Tolot (1971). Valeur et limite de dépistage clinique et biologique en pathologie industrielle. Archives des Maladies Professionnelles 32(1-2):56-66.

Milatovic D, Yin Z, Gupta RC, Sidoryk M, Albrecht J, Aschner JL, Aschner M (2007). Manganese induces oxidative impairment in cultured rat astrocytes. Toxicological Sciences 98:198-205. https://doi.org/10.1093/toxsci/kfm095

Missy P, Lanhers MC, Cunat L, Joyeux M, BurneL D (2000). Effects of subchronic exposure to manganese chloride on tissue distribution of three essential elements in rats. International Journal of Toxicology 19:313-321.

Molina RM, Phattanarudee S, Kim J, Thompson K, Wessling-Resnick M, Maher TJ, Brain JD (2011). Ingestion of Mn and $\mathrm{Pb}$ by rats during and after pregnancy alters iron metabolism and behavior in offspring. Neurotoxicology 32:413-422. https://doi.org/10.1016/j.neuro.2011.03.010

Moneim AEA, Dkhil MA, Al-Quraishy S (2011). The protective effect of flaxseed oil on lead acetate-induced renal toxicity in rats. Journal of Hazardous Materials 194:250-255. https://doi.org/10.1016/j.jhazmat.2011.07.097

Mostapha B, Adli Djallal EH, Miloud S, Wafaa A, Narimane T, Khaled K (2019). Evaluation of anti-oxidative effects of Mentha spicata essential oils in rats at the period of gestation and lactation co-exposed to lead and manganese. South Asian Journal of Experimental Biology 8(5):167-171.

Murray RL (1984). Creatinine. In: Clinical Chemistry: Theory, Analysis and Correlation. Kaplan LA, Pesce AJ (Eds). CV Mosby Co., St. Louis, pp 1247-1253.

Mylorie AA, Collins C, Umbles C, Kyle J (1986). Erythrocyte superoxide dismutase activity and other parameters of copper status in rats ingesting lead acetate. Toxicology and Applied Pharmacology 82:512-520. https://doi.org/10.1016/0041-008X(86)90286-3

Rotruck JT, Pope AL, Ganther HE (1973). Selenium: biochemical role as a component of glutathione peroxidase. Science 179:588-590. https://doi.org/10.1126/science.179.4073.588

Saka S, Bahi A, Aouacheri W (2011). The effect of oxidative stress induced by lead acetate on the glutathione enzymatic system in rats. Annales de Toxicologie Analytique 23(3):139-145. https//doi.org/10.1051/ata/2011123

Sánchez-González C, López-Chaves C, Gómez-Aracena J, Galindo P, Aranda P, Llopis J (2015). Association of plasma manganese levels with chronic renal failure. Journal of Trace Elements in Medicine and Biology 31:78-84. https://doi.org/10.1016/j.jtemb.2015.04.001

Singh RK, Gautam R, Karchuli MS (2014). Evaluation of nephroprotective activity of Mentha arvensis in cisplatininduced nephrotoxicity. Asian Journal of Pharmaceutical and Clinical Research 7(4):188-191.

Singh S, Shukla GS, Srivastava RS, Chandra SV (1979). The interaction between ethanol and manganese in rat brain. Archives of Toxicology 41:307-316. https://doi.org/10.1007/BF00296901

Sinha AK (1972). Colorimetric assay of catalase. Analytical Biochemistry 47:389-394. https://doi.org/10.1016/00032697(72)90132-7

Sivaprasad TR, Malarkodi SP, Varalakshmi P (2004). Therapeutic efficacy of lipoic acid in combination with dimercaptosuccinic acid against lead-induced renal tubular defects and on isolated brush-border enzyme activities. Chemico-Biological Interactions 147:259-271.

Small E, Catling PM (2000). Canadian medicinal cultures. NRC Research Press, pp 281.

Smith DM, Mielke HW, Heneghan JB (2008). Subchronic lead feeding study in male rats. Archives of Environmental Contamination and Toxicology 3:518-528.

Smith S, Gancarz D, Rofe F, Kempson IM, Weber J, Juhasz AL (2012). Antagonistic effects of cadmium on lead accumulation in pregnant and non-pregnant mice. Journal of Hazardous Materials 199:453-456. https://doi.org/10.1016/j.jhazmat.2011.11.016 
Suvarna SK, Layton C, Bancroft JD (2013). Bancroft's theory and practice of histological techniques. $7^{\text {th }}$ Ed. England. Churchill Livingstone. Elsevier

Toghyani M, Gheisari A, Ghalamkari GH, Mohammadrezaei M (2010). Growth performance serum biochemistry and blood hematology of broiler chicks fed different levels of black seed (Nigella sativa) and peppermint (Mentha piperita). Livestock Science 129:173-178. https://doi.org/10.1016/j.livsci.2010.01.021

Torres SJ, Nowson CA (2007). Relationship between stress, eating behavior, and obesity. Nutrition 23(11):887-894. https://doi.org/10.1016/j.nut.2007.08.008

Tsai MS, Liao KW, Chang CH, Chien LC, Mao IF, Tsai YA, Chen ML (2015). The critical fetal stage for maternal manganese exposure. Environmental Research 137:215-221. https://doi.org/10.1016/j.envres.2014.12.010

Ullah N, Khan AM, Khan T, Asif AH, Ahmad W (2014). Mentha piperita in nephrotoxicity - a possible intervention to ameliorate renal derangements associated with gentamicin. Indian Journal of Pharmacology 46(2):166-170. https://doi.org/10.4103/0253-7613.129309

Villeda-Hernandez J, Barroso-Moguel R, Mendez-Armenta M, Nava-Ruız C, Huerta- Romero R, Rios C (2001). Enhanced brain regional lipid peroxidation in developing rats exposed to low level lead acetate. Brain Research Bulletin 55(2):247-251. https://doi.org/10.1016/s0361-9230(01)00512-3

Wei MC, Zong WX, Cheng EHY, Lindsten T, Panoutsakopoulou V, Ross AJ, ... Korsmeyer SJ (2001). Proapoptotic BAX and BAK: a requisite gateway to mitochondrial dysfunction and death. Science 292:727-730. https://doi.org/10.1126/science.1059108

Yin Z, Aschner JL, dos Santos AP, Aschner M (2008). Mitochondrial-dependent manganese neurotoxicity in rat primary astrocyte cultures. Brain Research 1203:1-11. https://doi.org/10.1016/j.brainres.2008.01.079

Zargari A (2002). Medicinal plants. 2nd ed. Tehran University press, Tehran.

Zhang J, Cao H, Zhang Y, Zhanga Y, Maa J, Wang J, ... Chu L (2013). Nephroprotective effect of calcium channel blockers against toxicity of lead exposure in mice. Toxicology Letters 3:273-280. https://doi.org/10.1016/j.toxlet.2013.02.005

Zhao Q, Wang W, Cao Y, Chen Y, Ren A, Ge Y, ... Ruan L (2014). Potential health risks of heavy metals in cultivated topsoil and grain including correlations with human primary liver, lung and gastric cancer, in Anhui province, Eastern China. Science of the Total Environment 470:340-347. https://doi.org/10.1016/j.scitotenv.2013.09.086
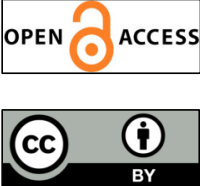

The journal offers free, immediate, and unrestricted access to peer-reviewed research and scholarly work. Users are allowed to read, download, copy, distribute, print, search, or link to the full texts of the articles, or use them for any other lawful purpose, without asking prior permission from the publisher or the author.

License - Articles published in Notulae Scientia Biologicae are Open-Access, distributed under the terms and conditions of the Creative Commons Attribution (CC BY 4.0) License.

(c) Articles by the authors; SHST, Cluj-Napoca, Romania. The journal allows the author(s) to hold the copyright/to retain publishing rights without restriction. 